DOI https://doi.org/10.18551/rjoas.2018-04.18

\title{
COMPETITIVENESS ANALYSIS OF FURNITURE INDUSTRY PRODUCTS IN PAPUA
}

\author{
Arung Lamba, Apolo Safanpo, Yohanes Rante \\ Faculty of Economics and Business, University of Cenderawasi, Jayapura, Papua, Indonesia \\ *E-mail: pr.arung.lamba@gmail.com
}

\begin{abstract}
The objective of this study is to analyze the influence of product, infrastructure, government policy, human resource, and science and technology on the competitiveness of furniture industry in the city and regency of Jayapura. The population of this study is 265 furniture industry business people and companies in the city and regency of Jayapura, from which 120 are selected as the sample through proportional sampling so that the sample is able to represent all characteristics in the population. This study uses descriptive analysis and Structural Equation Modelling to answer the research problem and assess the hypotheses. The results of this study show that product has a significant influence on competitiveness at 1.00 , that infrastructure has a significant influence on competitiveness at 1.604 , and that government policy has a significant influence on competitiveness at 0.815 . Furthermore, human resource and science and technology have a very significant influence on competitiveness at 1.269 and 1.012 consecutively.
\end{abstract}

\section{KEY WORDS}

Product, competitiveness, city, business, furniture.

In the spirit of equal right as citizens, small industry should grow and develop along with bigger industries, so this industry can give a significant contribution to the local, regional, and national economic growth. Furniture industry, which is a sub sector of small industry, is also expected to contribute considerably to the progress of economic development.

There are many small industries that have the potential to become a great business. However, other parties, such as the government, should participate in fostering them, particularly by solving problems frequently hinder them. The characteristics of small industries are small in business scale, limited in capital, usually using family members as labors, low in technology and market access, and traditional in management.

The modern economic theory was started in the time of Harrod and Domar. It emphasizes that economic growth is determined by two main components: investment and capital output ratio. Therefore, capital is an important in growth. Arthur Lewis (in Kartasasmita, 1997) emphasizes on surplus of labor by saying that productivity of high number of labor and low cost improves the amount of new investment. Further, small business is directed to improve competitiveness in order to become a strong and competitive business. In addition, small industry should emphasize more on employment improvement to develop the business.

The condition in Indonesia today is that non-metropolitan regions are potential for the growth of small industries that fulfill the demand of local market. However, small industries in rural areas do not develop significantly, where some of them are stagnant and even stop producing due to various problems. Small industries working in the regency and city of Jayapura work in various business units; one of them in furniture business.

The quantity of furniture industry in the regions increases and the business is scattered in some regions of urban industrial centers. This is very positive due to the fact that the existence of this industry has a strategic role for the development of settled industry and links between the production process and its down-stream industry. This because the availability of its raw material, i.e. wood and leather, is abundant in Papua. However, furniture business in the city and regency of Jayapura is still hindered by the following obstacles:

1. The business is still low in creativity, causing lower esthetic and unique products. 
2. Transportation to and from remote areas is still poor, electricity is still unreliable, low number of markets.

3. Government regulation tends to slow down the bureaucracy for business permit application, financial access for small business is very limited, and the government barely helps small industries make business partnership.

4. The education and the skill of human resource are low.

5. The availability and the use of science and technology are still limited.

Those are the main problems regarding the competitiveness of furniture industry in Papua. Therefore, it can be concluded that linkage needs mutual help and mutual benefit between small and medium and big industries followed by the role of small industry in supporting the need of medium and big industry for various components of their production result needs. However, the relationship between the two business groups has not reached a firm and controlled balance.

Competitive strategy is the search for beneficial competitive position in a competition, the fundamental arena where competition takes place. The objective of competitive strategy is to determine a beneficial position that can be defended against forces that determine industrial competition. There are two main questions that determines the option of competitive strategy; they are:

- Is the attractiveness of the industry able to generate long-term profit with the production factors at hand?

- Does the competitive strategy determine the relative competitive position in an industry?

The two questions above are inseparable in determining the appropriate competitive strategy. A company that is in a very attractive industry might not gain an attractive profit if it chooses a poor competitive strategy.

Industrial attractiveness and competitive strategy can actually be shaped by the company. This makes the choice of competitive strategy challenging and exciting. Although industrial attractiveness, which, some part of it, is a reflection of the company, has a little influence, competitive strategy has a great power to make industry become loess or more attractive (Porter Michael, 2004).

The opinion that the competitiveness is the foundation of regional economy that must be developed. This opinion is not exaggerating since the city and regency of Jayapura have many small industries that are less developed. Along with the era of decentralization and local economic development, the role of small industry is relevant for the success of the decentralization implementation.

Thus, it is necessary to conduct a research regarding industrial competitiveness, particularly in furniture industry, in order to improve working capability that, in the end, can improve success. Therefore, the objectives of this research are:

- to analyze and identify the influence of product on the competitiveness of furniture industry in the city and regency of Jayapura,

- to analyze and identify the influence of infrastructure on the competitiveness of furniture industry in the city and regency of Jayapura,

- to analyze and identify the influence of government policy on the competitiveness of furniture industry in the city and regency of Jayapura,

- to analyze and identify the influence of human resource on the competitiveness of furniture industry in the city and regency of Jayapura, and

- to analyze and identify the influence of science and technology on the competitiveness of furniture industry in the city and regency of Jayapura.

\section{LITERATURE REVIEW}

Competitiveness Theory. The concept of comparative advantage was initially introduced by David Ricardo in the early nineteenth century. The keyword is comparative, which is defined as relative. The meaning is that, for national scope, the economy of a 
country must produce goods that are relatively more efficient in its production and export the goods, and the country must import goods that are relatively smaller in profit (Theodorus Kuncoro, 2007).

The concept presented by David Ricardo is developed by Porter Michael (1990) in his theory entitled Competitive Strategy; Technique for Analyzing Industries and Companies, which is used as the grand theory of this study. Porter Michael stated that competitive advantage developed from values that can be created by a company for its customer, surpassing the cost of the company in creating it (product value $>$ product cost). Further, he mentioned that superior value came from price offered lower that competitors.

Factors that Influence Competitiveness. In a competition, there is sometimes a company that is in a weaker position, and there is a company in a stronger position. there are companies with strength, and there are companies with weaknesses. In other words, a company has competitiveness if the company controls $50 \%$ of the market. There are also companies categorized into monopolist, which have absolute control $(100 \%)$ over the market.

Agus Maulana (1990) asserted that, in the era that is full of competition nowadays, a businessperson who wants to open a new industry should answer the following questions.

1. Since no raw material means no production, is the raw material for the industry is adequate?

2. Since infrastructure is the basic facility that supports the process of an industry, is the infrastructure that supports the industry adequate?

3. Since government policy can either hinder or increase the process of a business, do applicable government policies give opportunities to the industry?

4. Since human resource is the motor for the activity, in management, technical, and labor matters, is the human resource at hand able to run the industry?

5. Since science and technology is the basic element for the ability to create or produce goods, is the existing science and technology able to process and produce goods?

6. Since market is the place to sell produced goods, is the market of the product sufficient?

The six matters above are necessary for a businessperson in planning to open an industry. Agus Maulana further stated that if a business starts to work, the next thing to be considered is whether the product can compete with other product from similar industry in the market.

Asrofi Almuhanam (2013) stated that there are several factors that influence a product in having competitive advantage in global and regional market. They are:

1. availability and quality of raw material,

2. availability and quality of human resource,

3. availability and quality of science and technology,

4. availability and quality of infrastructure, and

5. support of government policy.

Theodorus Kuncoro (2007) stated that science and technology of an individual or a business institution improves the chances of its owner to produce superior products. Relevant to the opinion of four experts above, Piter Abdullah et al. (2012) mentioned in their book six variables that influence the competitiveness of small industry. They are raw material, product quality, human resource, science and technology, infrastructure, and government policy.

Porter Michael concluded that several countries succeed in certain industries the environment the industries originating from is visionary, dynamic, and challenging. He added that there are four important domestic variables that are individually and compositely determine the competitiveness of a country. They are the condition of its infrastructure, the condition of its human resource, the condition of its science and technology, the condition of its product, and competitive strategy in small industry.

Terence in Tulus Tambunan (2011) assumed that the scope of competition where a company is engaged in is the characteristic and behavior of certain business competitors and key determinant the strategy and sustainability of the company. However, new managers, in 
general, can do validation after they know the real condition faced by the company. Based on the descriptions above, there two important things. They are:

1. to survive in the competition, strategy developers should know more than just relevant implementation measurement in an industry. They must develop ways to obtain validity regarding relationship among them. A way that can be developed is a strategic map that describes the measurement of gains (e.g. return on investment and market share),

2. tactics and strategies that deals with the existing reality regarding competitors' gain. This data give an adequate assurance so that this kind of mapping strategy can be developed for industries that are capable of performing it.

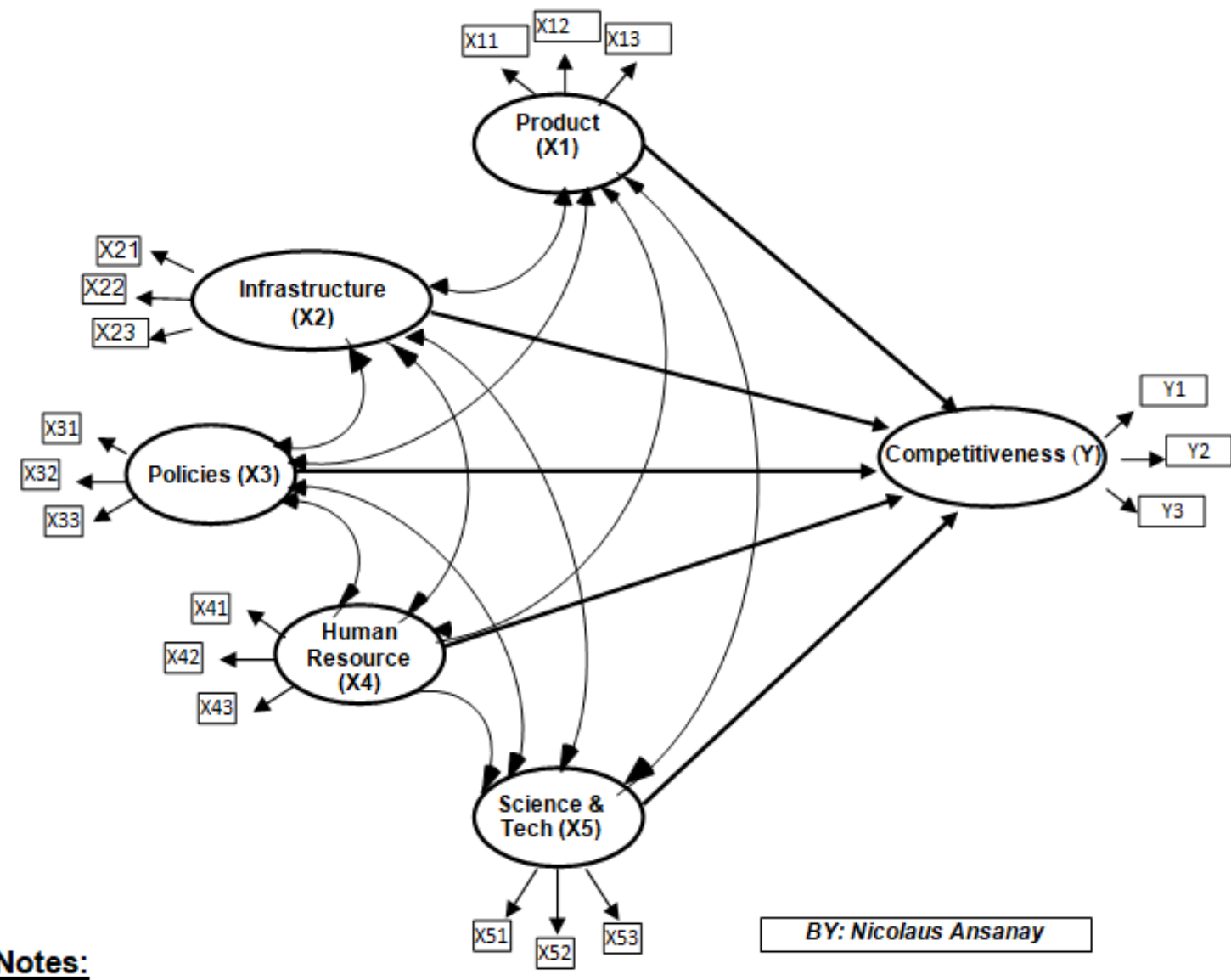

\section{$\mathrm{X} 1$ = Product}

$\mathrm{X} 11=$ Efficiency of Production Process

$\mathrm{X} 12=$ Esthetic

$\mathrm{X} 13=$ Uniqueness

X $4=$ Human Resource

$\mathrm{X} 41=$ Number

$\mathrm{X} 42$ = Education

$\mathrm{X} 43=$ Skill

\section{$\mathrm{X} 2$ = INFRASTRUCTURE}

X21 = Transportation facilities

X5 = SCIENCE AND TECHNOLOGY

X22 = Market facilities

X23 = electricity, telephone lines, clean water

$\mathrm{X} 51=$ Development activities

X52 $=$ Tools availability

X53 = Experts availability

X3 = Government Policy

$\mathrm{X} 31=$ Easiness of business licensing

X32 = Financial aid

X32 = Business partnership

\begin{tabular}{l}
$Y=$ COMPETITIVENESS \\
\hline$Y 1=$ Price \\
$Y 2=$ Quality \\
$Y 3=$ Innovation
\end{tabular}

Source: Dong-Sung Cho-Chang Moon (2013), Munrokhim (2009); Piter Abdullah et al. (2012), summarized and developed by the author.

Figure 1 - Concept on the Relationship among Variables Together with Their Indicators: 


\section{RESULT OF STUDY}

$\begin{array}{ll}\text { Chi-Square }=70.484 & \text { AGFI }=0,888 \\ \text { Probability }=0,066 & \text { TLI }=1,039 \\ \text { CMIN } / D F=0,926 & \text { CFI }=1,000 \\ \text { GFI }=0,929 & \text { RMSEA }=0,000\end{array}$

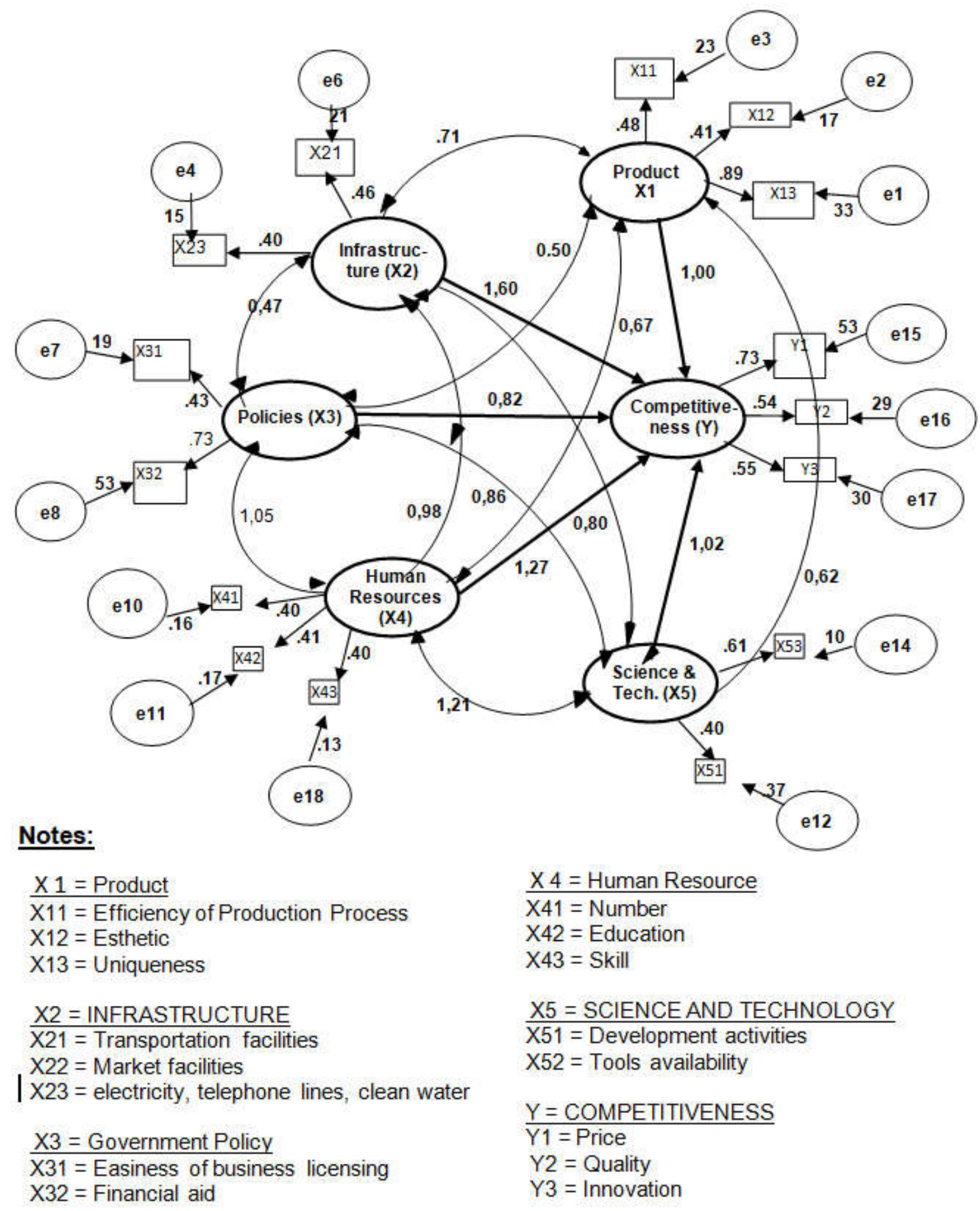

Figure 2 - Result of Modified SEM

Referring to the result of modified SEM above, the following structural equation is formulated:

$$
\text { D.S }=1,00 \mathrm{Pr}+1,60 \text { I.S + 0,82 K.P + 1,27 SDM + 1,02 I.T }
$$


The result of the assessment on the modified model indicates eligible coefficients. The result of the assessment on the modified model is elaborated in figures presented in the table below.

Table 1 - The result of the Assessment on the Modified SEM

\begin{tabular}{|c|c|c|c|}
\hline Model Relevance & Criteria & Coefficient & Remark \\
\hline Chi Square & Small & 70.40 & Fulfilled \\
\hline Significance Probability & $\geq 0.05$ & 0.66 & Fulfilled \\
\hline RMSEA & $\leq 0.08$ & 0.00 & Fulfilled \\
\hline GFI & $\geq 0.90$ & 0.93 & Fulfilled \\
\hline AGFI & $\geq 0.90$ & 0.89 & Fulfilled \\
\hline CMIN/DF & $\leq 2.00$ & 1.93 & Fulfilled \\
\hline TLI & $\geq 0.95$ & 1.04 & Fulfilled \\
\hline CFI & $\geq 0.95$ & 1.00 & Fulfilled \\
\hline
\end{tabular}

Source: Research result, 2017.

Based on the table above, it can be concluded that the model does not contain correlation mistakes among covariant. Therefore, the newly obtained model has fulfilled the elements of model relevance and integration, so analysis can proceed.

The modification results in a new model, as seen in the modified model above. The next step is performing model measurement test or confirmatory factor analysis, which is used to measure the relationship between latent variables and their indicators, which is by comparing the loading factor coefficient with the significance level at $\alpha=5 \%$.

Assessment Result (Measurement Model/Confirmatory Factor Analysis). After performing model relevance assumption test above, which found that the new model has a good relevance, data analysis is performed to obtain a clear description about the relationship of each indicator in each variable. To identify it, the following tables of Loading Factor Confirmatory Model and Critical Ratio are used.

Table 2 - Regression Weight (Loading Factor Confirmatory) Model

\begin{tabular}{|c|c|c|c|c|c|}
\hline No & Indicator & $\longleftarrow$ & Variable & $\begin{array}{l}\text { The best Standardized Estimate } \\
\text { (loading Factor) }>0,4\end{array}$ & Remark \\
\hline \multicolumn{6}{|c|}{ Product } \\
\hline 1 & $\mathrm{X} 11$ & $\overline{-}$ & Production & 0,48 & Positive \\
\hline 2 & $\mathrm{X} 12$ & $\overline{-}$ & Production & 0,41 & Positive \\
\hline 3 & $\mathrm{X} 13$ & $\overline{-}$ & Production & 0,58 & Positive \\
\hline \multicolumn{6}{|c|}{ Infrastructure } \\
\hline 1 & $\mathrm{X} 21$ & - & Infrastructure & 0,46 & Positive \\
\hline 2 & $\mathrm{X} 23$ & - & Infrastructure & 0,40 & Positive \\
\hline \multicolumn{6}{|c|}{ Government Policies } \\
\hline 1 & $\mathrm{X} 31$ & {[} & Govt. Policies & 0,43 & Positive \\
\hline 2 & $\mathrm{X} 32$ & {[} & Govt. Policies & 0,71 & Positive \\
\hline \multicolumn{6}{|c|}{ Human Resource } \\
\hline 1 & $\mathrm{X} 41$ & E- & Human Resource & 0,40 & Positive \\
\hline 2 & $\mathrm{X} 42$ & $\overline{-}$ & Human Resource & 0,41 & Positive \\
\hline 3 & $\mathrm{X} 43$ & E- & Human Resource & 0,40 & Positive \\
\hline \multicolumn{6}{|c|}{ Science and Technology } \\
\hline 1 & $\longleftarrow$ & $\overline{-}$ & Science \&Tech. & 0,40 & Positive \\
\hline 2 & $\mathrm{X} 53$ & $\overline{-}$ & Science \&Tech. & 0,61 & Positive \\
\hline \multicolumn{6}{|c|}{ Competitiveness } \\
\hline 1 & $\longleftarrow$ & - & Competitiveness & 0,73 & Positive \\
\hline 2 & $\mathrm{Y} 2$ & & Competitiveness & 0,54 & Positive \\
\hline 3 & Y3 & & Competitiveness & 0,55 & Positive \\
\hline
\end{tabular}

Source: Research result, 2017. 
Table 3 - Critical Ratio Indicator of Product, Infrastructure, Government Policies, Human Resource, Science and Technology, and Competitiveness

\begin{tabular}{|c|c|c|c|c|c|}
\hline No & Indicator & Estimate & $\begin{array}{c}\text { CR condition } \\
>1,96\end{array}$ & $\begin{array}{l}\text { Probability }(\mathrm{P}) \\
\text { condition }<0,05\end{array}$ & Remark \\
\hline \multicolumn{6}{|c|}{ Factor Product } \\
\hline 1 & X11 $\longleftarrow$ Product & 0.858 & 3.100 & 0.002 & Significant \\
\hline 2 & X12 $\longleftarrow$ Product & 0.753 & 2.895 & 0.004 & Significant \\
\hline 3 & $\mathrm{X} 13 \longleftarrow$ Product & 1.000 & 4.025 & ${ }^{*} . * \star \star \star$ & Very Significant \\
\hline \multicolumn{6}{|c|}{ Factor Infrastructure } \\
\hline 1 & $\longleftarrow$ Infrastructure & 0.952 & 2.760 & 0.006 & Significant \\
\hline 2 & Infrastructure & 1.000 & 3.678 & ${ }^{*}{ }^{* * * *}$ & Very Significant \\
\hline \multicolumn{6}{|c|}{ Government Policies } \\
\hline 1 & 4 Govt. Policies & 0.942 & 4.019 & 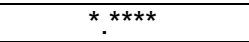 & Significant \\
\hline 2 & X32 $\longleftarrow$ Govt. Policies & 1.545 & 5.597 & ${ }^{*} . * * \star$ & Significant \\
\hline \multicolumn{6}{|c|}{ Human Resource } \\
\hline 1 & $\mathrm{X} 41 \longleftarrow$ Hum. Res. & 1.000 & 2.468 & $*{ }^{* \star \star \star \star *}$ & Very Significant \\
\hline 2 & $\mathrm{X} 42 \longleftarrow$ Hum. Res. & 0.991 & 3.436 & 0.001 & Significant \\
\hline 3 & $\mathrm{X} 43 \longleftarrow$ Hum. Res. & 0.856 & 3.175 & 0.001 & Significant \\
\hline \multicolumn{6}{|c|}{ Science and Technology } \\
\hline 1 & Science \& Tech & 1.000 & 2.754 & ${ }^{*}{ }^{* \star \star \star}$ & Very Significant \\
\hline 2 & Science \& Tech & 1.731 & 3.013 & 0.003 & Significant \\
\hline \multicolumn{6}{|c|}{ Competitiveness } \\
\hline 1 & Y1 $\longleftarrow$ Competitiveness & 1.239 & 4.645 & ${ }^{*} . * * *$ & Very Significant \\
\hline 2 & Y2 $\longleftarrow$ Competitiveness & 0.331 & 4.098 & $* * * * *$ & Very Significant \\
\hline 3 & Y3 & 1.000 & 3.465 & $\star{ }^{* \star \star *}$ & Very Significant \\
\hline
\end{tabular}

Source: Research result, 2017ю

\section{DISCUSSION OF RESULTS}

Referring to the data analysis above, which is the result of modified SEM, the following path coefficient showing the influence of product, infrastructure, government policies, human resource, and science and technology on the competitiveness of furniture industry product in the city and regency of Jayapura is obtained.

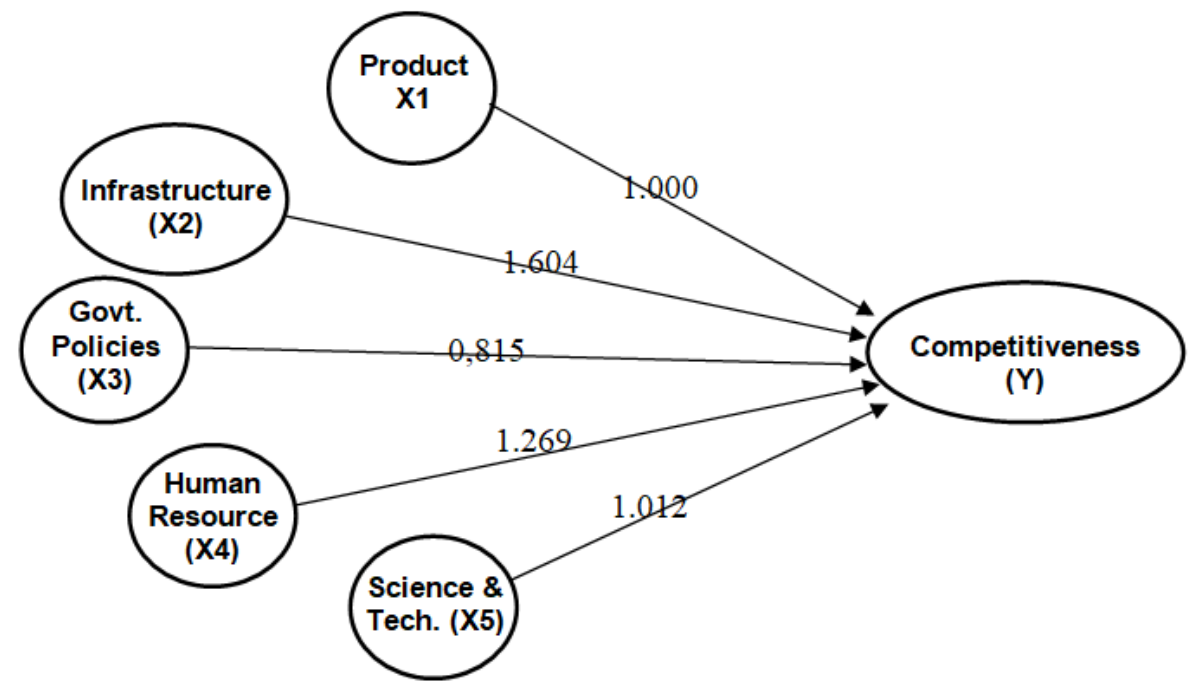

Source: Research result, 2017.

Figure 3 - Path Coefficient of the Influence of Independent Variables on Dependent Variable

For the purpose of discussion, the chart of path coefficient of the influence of independent variables on dependent variable needs to be attached with table of calculation, SE, C. R., and probability as follows. 
Table 4 - The Influence of Independent Variables on Dependent Variable

\begin{tabular}{|lll|c|c|c|c|c|}
\hline \multicolumn{3}{c}{ Variables } & Path Coeff. & SE & C.R & Probability & Remark \\
\hline Competitiveness & Product & 1.000 & 0,421 & 2.011 & 0,002 & Very Significant \\
\hline Competitiveness & Infrastructure & 1.604 & 1.019 & 2.574 & 0,023 & Significant \\
\hline Competitiveness & Gov. Policies & 0.815 & 0.279 & 2.924 & 0.034 & Significant \\
\hline Competitiveness & & Human resource & 1.269 & 0.097 & 2.125 & 0.008 & Very Significant \\
\hline Competitiveness & Science \& Tech. & 1.012 & 0.499 & 2.028 & 0.004 & Very Significant \\
\hline
\end{tabular}

Source: Research result, 2017.

Based on the assessment using AMOS 4 through Structural Equation Modelling (SEM) and Path and Multiple Regression analysis above, the following is the discussion.

The Influence of Product on the Competitiveness of Furniture Industry Product. The result of Structural Equation Modelling (SEM) using AMOS 4 (as seen in table 6.1 and 6.2) shows that the critical ratio of the influence of product on the competitiveness of furniture industry product is 2.011 (fulfilling the requirement of $>1.96$ ). The values of path coefficient of 1.00 define the magnitude of the influence, standard error of 0.421 defines the positiveness of the influence, and probability of 0.002 defines the significance of the influence.

Based on the result analysis above, the influence of product on the competitiveness of furniture industry product is positive and significant, and the magnitude of the influence is 1.00. This finding is supported by the descriptive analysis that has been conducted previously, because, of the three indicators used to measure product, only efficiency of production process that is in medium level, while Aesthetic and uniqueness is still low.

Aesthetic and uniqueness that is not present in local furniture product is in variations of types and modification of models in products of living room chairs and tables, office cabinets and tables, and kitchen cabinets and shelves.

This finding supports the result of Gale Brandeley T (1995) that profits are earned by a company because it provides high quality products with attractiveness in aesthetic and uniqueness. Higher efficiency in its production process will increase selling revenues and lower the cost, so customers will be more interested in choosing the product compared to that of the competitors.

This finding also supports David A. Garvin (1997) that identifies that the quality of a product is observable from eight dimensions; they are artistic, uniqueness, durability, fineness, material availability, appropriateness with local preferences, appropriateness with needs, and price level.

The Influence of Infrastructure on the Competitiveness of Furniture Industry Product. The result of the assessment shows that the influence of infrastructure on the low competitiveness of the product. This is shown by the value of path coefficient, which is 1.604 , that shows the magnitude of the influence, with the probability of 0.015 that shows a significant value, and the standard error value of 1.109 that shows the positiveness of the influence.

The value of the path coefficient of 1.604 shows that the influence of infrastructure on the competitiveness of the furniture product is quite reasonable because, in fact, the infrastructure in the city and regency of Jayapura is not sufficient to support competitiveness that requires good infrastructure, electricity, telecommunication, and water supply. Therefore, improvement in the availability of clean water and electricity in furniture industry center is needed because the state's water and electricity company in Papua, in general, can only support household needs. In fact, furniture industry in the city and regency of Jayapura is still attached to residential activities.

This finding is also supported by the fact that the infrastructure is very low in improving competitiveness of furniture industry product, which is shown by the total score of 349 , lower than medium score of 360 .

The low influence of infrastructure in supporting competitiveness of furniture industry product can be seen from three indicators that are used to measure the condition of the infrastructure. Electricity, telephone lines, and clean water, in fact, are lower than medium category. However, market and transportation are above medium category. 
This finding supports the theory of Glueck William F and Jauch $\mathrm{CH}$ (2001) that external environment (infrastructure) influences business development, which in turn, will influence competitiveness. Good infrastructure will make companies easy to develop themselves and serve their customers. This means that development and improvement in customer service will create better competitiveness for the companies.

Further, Glueck William asserted that infrastructure, in supporting the competitiveness of industry, should be based on the principles of 1) physical capital in the form of infrastructure, in its quality and quantity, must support regional economic activities; 2) natural capital in terms of geographical condition and natural resource contained in it should be able to support the existing industrial production.

This finding is also relevant with the result of Theodorus Kuncoro (2007) that the influence of infrastructure is quite reasonable because, in fact, the infrastructure in the city of Pasuruan, i.e. road, electricity, telecommunication, and clean water, is quite sufficient for metal industry competition. However, addition of clean water facilities in metal small industry center is needed because the water company (PDAM) can only supply 34 units of industry. The total units of industry in this city is 873 , which means that the water company can only serve $4 \%$ of the industry.

The Influence of Government Policy on the Competitiveness of Furniture Industry Product. The result of the assessment of the influence of government policies on the low competitiveness of furniture industry product shows that the Critical Value ratio is 2.294, which has fulfilled the requirement of $>1.96$. The value of path coefficient, which shows the magnitude of the influence, is 0.815 , the value of standard of error, which shows the positiveness of the influence, is 0.279 , and the value of probability is 0.034 , showing that the influence is significant.

Based on the analysis result above, the influence of government policies on the competitiveness of furniture industry product in the city and regency of Jayapura is positive and significant with influence magnitude of 0.815 .

This finding is supported by the descriptive analysis that has been conducted previously, which is the empirical condition in the field, because, of the three indicators, only one indicator whose position is slightly above medium, which is easiness in business licensing (total score of 363). Two other indicators, i.e. financial aid and business partnership are below medium criteria (total score of, respectively, 353 and 339). Therefore, it can be concluded that government policies do not contribute much to improve furniture industry in the city and regency of Jayapura in terms of competitiveness.

This finding supports Supriyono (1999) and Glueck William F and Jauch CH (2003), who suggested that competitiveness in various kinds of industry from a region is actually inseparable from policies applied by the government of the region. It means that the more the policies taken by the local government focused on the development of industry, the better the possibilities of the products from the industry in the region to have competitiveness against similar products from other regions or countries. Siagian (2005) also said that the condition of government policies influenced the competitiveness of a product.

This finding is also relevant to the result of Badudu M (2007), who conducted a research in several major cities in Indonesia, and Tajerin (2004). They found that policies applied by the government will be very influential on the competitiveness of an industrial product.

The Influence of Human Resource on the Competitiveness of Furniture Industry Product. The result of the analysis on the influence of human resource on the competitiveness of furniture industry product in the city and regency of Jayapura shows that the critical ratio is 2.011 (fulfilling the requirement of $>1.96$ ). The values of path coefficient of 1.269 define the magnitude of the influence, standard error of 0.097 defines the positiveness of the influence, and probability of 0.008 defines the significance of the influence.

Based on the analysis result above, the influence of human resource on the competitiveness of furniture industry is positive and very significant with influence magnitude of 1.269 . 
This finding is supported by the descriptive analysis that has been conducted previously, which shows that, of the three indicators that are used to measure the influence of human resource on furniture industry, there are two indicators whose position are slightly above medium; they are number of labors (364) and skill (361). However, education is below medium criteria (336). Therefore, it can be concluded that human resource gives a moderate contribution in improving furniture industry in terms of competitiveness.

This finding is relevant with the result of two researchers; they are Djiwanto (2012) and Suparyadi (2004). They found that the quality of competitive advantage of industrial product is very much influenced by the quality and quantity of labors used in the industry. Further, Suparyadi (2004) explained that the quality of human resource depends on the education of skill at hand.

This finding also supports the opinion of two experts; they are Dong-Sung Cho-Chang Moon (2013) and Kartasasmita Ginanjar et al. (1990). They include human resource as one of the factors that are very important in influencing the competitiveness of an industrial product.

The Influence of Science and Technology on the Competitiveness of Furniture Industry Product. The result of the assessment of the influence of science and technology on the low competitiveness of furniture industry product shows that the Critical Value ratio is 2.028, which has fulfilled the requirement of $>1.96$. The value of path coefficient, which shows the magnitude of the influence, is 1.012, the value of standard of error, which shows the positiveness of the influence, is 0.499 , and the value of probability is 0.004 , showing that the influence is very significant since the value is approaching 0 .

Based on the analysis result above, the influence of science and technology on the competitiveness of furniture industry product in the city and regency of Jayapura is positive and very significant with influence magnitude of 1.012 .

This finding is supported by the descriptive analysis that has been conducted previously, which is the empirical condition in the field, because the total score of the three indicators that are used to measure the condition of science and technology are below medium. The lowest score is availability of experts (335), followed by development activities (341), and availability of tools (351). Therefore, it can be concluded that the most influential indicator in the category of science and technology is availability of experts, with the total score of 335 .

This finding supports the opinions of several experts, i.e. Porter Michael (2004), Eduardus Tandelilin (2002), and Sugiyono Dirgantoro (2012). They asserted that the higher the science and technology used or owned by any industry will improve the chance of the industry to produce goods with high competitiveness. This means that science and technology used in the production determines the competitiveness of an industrial product.

This finding is also relevant with the result of Theodorus Kuncoro (2007), and Asrofi Almuhanam (2013). They found that the availability and the good use of science and technology will influence the competitiveness of an industrial product.

\section{CONCLUSION}

The conclusion of this study is that the influence of product, infrastructure, government policies, human resource, and science and technology on the competitiveness of furniture industry in the city and regency of Jayapura is positive at various levels. The order of the influence of each factor based on the magnitude of the influence is as follows:

- Infrastructure with significant influence at 1.604 .

- Human resource with very significant influence at 1.269.

- Science and technology with very significant influence at 1.012 .

- Product with significant influence at 1.00.

- Government policies with significant influence at 0.815 . 


\section{SUGGESTIONS}

To the Government. The government must gain trust from related parties regarding the furniture industry product from the city and regency of Jayapura that the product is the featured product of the region through:

- Local fiscal policies (local budget) that are prioritized to support the business of small furniture industry in forms of assistance program (provision of experts) particularly that deals with technology transfer; and

- Information network facility that can inform the potential and ability of the furniture industry in improving their marketing access.

To Small Industry. Must emphasize more on the (high) aesthetic in all products:

- Must show uniqueness in all products, and

- Must establish business network among small furniture industries, which can help improve marketing distribution channel.

To Other Researchers:

- Follow up research is needed by including factors other than product, infrastructure, government policies, human resource, and science and technology, so the role of the other factors in improving competitiveness can be identified, and

- Follow up research regarding competitiveness in industries other than small furniture industry is also needed.

\section{REFERENCES}

1. Agus Maulana. 1990. Strategi Bersaing, Teknik Menganalisa Industri dan Pesaing, Penerbit PT Erlangga, Jakarta.

2. Apibunyopas Preeyanuch. 1993. An Analysis of Faktors Affecting the Performance of small Rural Non Firm-Firm in Thailand, un Published Phd Disertation, Purdue University, Thailand.

3. Arung Lamba. 2014. Peningkatan Mutu Pangan Petani Asli Papua (Kajian Strategis Di Kabupaten Jayapura, UNCEN Press, Jayapura.

4. Asrofi Almuhanam. 2013. Keunggulan Bersaing (Comvettive Advan Tage) Jasa angkutan umum di Surabaya, Disertasi Program Pasca Sarjana ITS, Surabaya.

5. Badudu M. 2007. Kebijakan Pemerintah Dan Pengembangan Usaha Kecil Di Indonesia, Penerbit; Pustaka Sinar Harapan, Jakarta.

6. Badan Pusat Statistik (BPS). 2015. Papua Dalam Anggka Tahun 2015, Provinsi Papua

7. Crown Dirgantoro. 2012. Keunggulan Dalam Bersaing Melalui Proses Bisnis, PT Gramedia Widiasarana Indonesia, Jakarta.

8. David A Garvin. 1997. Computing on The Eight Demensions of Quality Harvad Business Review, November, Cambridge University Press, New York.

9. Djiwanto. 2012. Analisis Pengaruh Perkembangan Sumberdaya Manusia Dan Strategi Bersaing Serta Kebijakan Pemerintah dalam meningkatkan Prestasi Kerja dan kualitas produksi di Daerah Sentra Industri Jawa Timur, Disertasi S3 UNAIR, Surabaya.

10. Djumiati. 2007. Analisa Efisiensi Penggunaan Tenaga Kerja Sebagai Dasar Dalam Menyususn Perencanaan Tenaga Kerja Pada Sektor Industri Kecil di Jawa Timur, Disertasi S3 UNAIR, Surabaya.

11. Dong-Sung Cho-Chang Moon. 2013. Evaluasi Teori Daya Saing, Penerbit Salemba Empat, Jakarta.

12. Eduardus Tandelilin. 2002. tentang Peranan Strategi Operasi Dalam Menciptakan Keunggulan Bersaing Penerbit: Center Of Economic Sosial Studies, Jakarta.

13. Suratno Josoharjono, 2006; Ekonomi Produksi Suatu Analisis Dalam Persaigan Bisnis, Gaja Mada Press, Jogjakarta.

14. Gale Brandeley T. 1995. Formulating of Quality Improvement Strategy, Journal of Business Strategy 5 Winter 21. 
15. Glueck William F dan Jauch CH. 2003. Analisa Strategi dan kebijakan Pemerintah Dalam Daya Saing Bisnis (Terjemahan Supriono) Edisi I Erlangga, Jakarta.

16. Hadi Sutrisno. 2004. Metodologi Reseack, Cetakan XV, Penerbit Andy Offset, Yogjakarta

17. Haris A. 2009. Pengaruh Penatagunaan Tanah Terhadap Keberhasilan Pembangunan Infrastruktur dan Ekonomi, http:/www. Bappenas.go.id/node/71/1195.

18. Ida Suntono, \& Yundyana Antarasi. 2013. Infrastruktur dan Daya Saing Industri-Industri Kecil Di Indonesia, Suatu Kajian IImiah, Penerbit; Pustaka Binaman Presindo, Jakarta

19. Kartasasmita, Ginanjar. 1997. Pembangunan Untuk Rakyat, Memadukan Pertumbuhan Dan Pemerataan, Penerbit Cides, Jakarta

20. Kartasasmita, Ginanjar et al. 1990. Ekonomi Sumberdaya Manusia, Masalah, Tantangan Dan Strategi Pengembangan Serta Daya Saing, IKIP, Malang

21. Marbun B N. 1996. Kekuatan dan Kelemahan Dalam Perusahaan Kecil (sector informal), Pustaka Binaman Presindo, Jakarta

22. Mudrajat Koncoro. 2007. Ekonomi Industri, Teori Kebijakan dan Studi Empiris Di Indonesia, Widya Sarana Informatika, Jakarta.

23. Munrokhim M. 2009. Ekonomi Pembangunan, Penerbit Fak Ekonomi UII Sleman, Jakarta

24. Piter Abdullah dkk. 2012. Daya Saing Industri, Konsep dan Pengukurannya, BPFE, Yogjakarta.

25. Poter Michael. 1990. Competitive Strategy; Technique for Analizing Industries and Companies, Fress Press, New York.

26. 2004. Keunggulan Bersaing (Menciptakan dan Mempertahankan), Penerbit Bina Aksana, Jakarta.

27. 2010. Keunggulan Bersaing Dalam Industri, Terjemahan, Penerbit Bynapura Aksara, Jakarta.

28. Rahardiana. 2014. Analisis Penetapan Strategis Keunggulan Bersaing Melalui Pengintegrasian Supply Choin Untuk Menciptakan Nilai Keunggulan Biaya di PT. ILUFA Pasuruan, Kerjasama antara Pemda Pasuruan dengan Universitas Brawijaya, Malang

29. Siagian. 2005. Analisa Pengaruh Kebijakan Terhadap Daya Saing Produk Industri, Penerbit Bumi Aksara, Jakarta

30. Simanjuntak. 2002. Analisa Daya Saing Industri Kecil, Penerbit Bynapura Aksara, Jakarta

31. Soetriono. 2016. Analisa Daya Saing Dalam Produk-Produk Pertanian di Malang, Jawa Timur, Bayu Media, Surabaya.

32. Sugiyono Dirgantoro. 2012. Keunggulan Bersaing Melalui Proses Bisniss, PT Gramedia Widiasarana Indonesia, Jakarta.

33. Supriyono. 1999. Kebijakan Pemerintah Daerah Dalam Prespektif Industri Kecil. Penerbit PT Rajawali Press, Jakarta

34. Suparyadi. 2004. Membangun Keunggulan Bersaing Industn Gula Merah Tebu di Endrekang Disertasi, Program Doktor IImu Ekonomi, Universitas Hasnuddin, Makassa

35. Surachmad Winarno. 1990. Dasar dan Teknik Research, Penerbit CV. Tarsito, Bandung

36. Swastha. 2002. Pengaruh ketidakpuasan konsumen, kategoni produk, dan kebutuhan mencari variasi terhadap keputusan perpindahan merk. Penerbit; BPEE Universitas Gajamada, Yogjakarta.

37. Tajerin. 2004. Daya Saing Udang di Indonesia Sebuah analisis dengan pendekatan Pangsa Pasar; Disertasi, Program Doktor Ilmu Ekonomi, Universitas Indonesia, Jakarta

38. Theodorus Kuncoro. 2007. Analisis Faktor-Faktor Yang Mempengaruhi Daya Saing Industry Kecil Di Pasuruan Jawa Timur, Disertasi , Program Doktor Fakultas Ekonomi Universitas Brawijaya, Malang.

39. Tulus Tambunan. 2011. Industrialisasi di Negara Sedang Berkembang, Kasus Indonesia, Cetakan Pertama, Ghalia Indonesia, Jakarta.

40. Winato dan Siregar. 2006. Merencanakan Sistim Perangkutan Di Kota Bandung, penerbit ITB Press, Bandung. 